\title{
EFFECTS OF COPPER AND VERMICOMPOST ON GROWTH AND YIELD OF COWPEA (Vigna unguiculata L.) Walp AND NUTRIENT ACCUMULATION IN ITS FRUITS
}

\author{
Sharif, A. T., A. H. M. Z. Ali and M. K. Rahman \\ Department of Soil, Water and Environment, University of Dhaka, Dhaka-1000, Bangladesh
}

\begin{abstract}
The effects of copper $(\mathrm{Cu})$ and vermicompost $(\mathrm{VC})$ on growth and yield of cowpea (Vigna unguiculata L.) Walp and nutrient accumulation in its fruits was examined. Eight treatments of $\mathrm{Cu}$ and $\mathrm{VC}$ were used. The highest plant height $(226.67 \mathrm{~cm})$, leaf number per plant $(86.33)$, leaf area $\left(174.12 \mathrm{~cm}^{2} / \mathrm{plant}\right)$, dry weight $(13.98 \mathrm{~g} / \mathrm{plant})$, fruit length $(52.4 \mathrm{~cm})$, fruit number per plant $(6)$, and fruit yield $(5.65 \mathrm{~g} / \mathrm{plant})$ were recorded in $\mathrm{Cu}_{0.5} \mathrm{~kg} / \mathrm{ha}+\mathrm{VC}_{5}$ ton/ha treatment at harvest. The results of growth and yield of cowpea varied significantly $(\mathrm{p} \leq 0.05)$ and increased with time. The total nutrient concentrations in the fruits were measured and varied significantly $(\mathrm{p} \leq 0.05)$. The highest concentration of total P $(0.79 \%), \mathrm{K}(4.14 \%), \mathrm{S}(0.42 \%), \mathrm{Cu}(27$ $\mathrm{mg} / \mathrm{kg}), \mathrm{Fe}(640 \mathrm{mg} / \mathrm{kg})$ and $\mathrm{Mn}(59 \mathrm{mg} / \mathrm{kg})$ in the fruits were observed in $\mathrm{Cu}_{0.5} \mathrm{~kg} / \mathrm{ha}+\mathrm{VC}_{5}$ ton/ha treatment and total $\mathrm{N}(4.29 \%)$ and $\mathrm{Zn}(88 \mathrm{mg} / \mathrm{kg})$ were found in $\mathrm{Cu}_{1.5} \mathrm{~kg} / \mathrm{ha}+\mathrm{VC}_{5}$ ton $/ \mathrm{ha}$ treatment. The overall best growth, yield and nutrient accumulation in the fruits of cowpea were achieved in $\mathrm{Cu}_{0.5} \mathrm{~kg} / \mathrm{ha}+\mathrm{VC}_{5}$ treatment.
\end{abstract}

Key words: Copper; Cowpea; Growth; Nutrient accumulation; Vermicompost.

\section{INTRODUCTION}

Balanced supply of essential nutrients is one of the most important factors in increasing crop yields. The functions of copper in the plants are to metabolize nitrogen and carbohydrate and to synthesize lignin. It also affects flavour and coloring of the vegetables and their storage ability, which aids to the prevention of diseases. In $\mathrm{Cu}$ deficient soil, roots are vulnerable to fungal and bacterial attack (Mordtvedt et al. 1991). Vermicomposting is a process of bio transforming and stabilizing organic materials (often waste) into humus by the combined activity of earthworms and microorganisms (Aira and Dominguez 2008). Vermicompost is finely divided peat-like materials with high porosity, aeration, drainage, and water-holding capacity. Vermicompost contains nutrients in the forms that are readily taken up by the plants and is a low-cost product. They are organic fertilizer and helps in reducing environmental pollution due to chemical fertilizers. An annual legume, cowpea is perhaps the oldest source of human food even though, acquisition with varied range of soils and rainfall patterns has yet confined to the arid and semi-arid regions world over. Cowpea is one of the pulse crops with proteinaceous seeds. Although suitable to grow at all regions of Bangladesh, it is extensively grown in the southern part in the rice-based cropping systems after the harvest of transplant aman rice (Rahman 1989). It is estimated that the annual world cowpea crop is grown on 12.5 million ha, and the total grain production is 3 million tons. West and Central Africa is the leading cowpea producing region in the world; this region produces $64 \%$ of the estimated 3 million tons of cowpea seed produced annually. Cowpea seed consists of $25 \%$ protein and has very low fat content (Rangel et al. 2003). Cowpea starch is digested more slowly than the starch from cereals, which is more beneficial to human health. The grain is a rich source of folic acid, an important vitamin that helps prevent neural tube defects in unborn babies (Witthoft et al. 2016).

A limited works have been done on the effects of fertilizers particularly of copper and vermicompost on cowpea. Hence, an experiment was conducted to evaluate the effects of copper and vermicompost on growth, yield and nutrient accumulation in the fruits of cowpea. 


\section{MATERIAL AND METHODS}

Soil sample collection and some physical and chemical properties

Soil sample (0-15 cm depth) was collected from Dhamrai, Savar. The sample was air-dried, ground and sieved through $2 \mathrm{~mm}$ sieve. The soil had a $\mathrm{pH}$ of 7.54 (1:2.5 w/v H $\mathrm{H}_{2} \mathrm{O}$, Jackson 1965), Electrical Conductivity $49.9 \mathrm{ds} / \mathrm{m}\left(1: 5 \mathrm{w} / \mathrm{v} \mathrm{H}_{2} \mathrm{O}\right.$, Jackson 1965), organic carbon $0.156 \%$ (Walkley and Black 1934), organic matter $0.27 \%$, available nitrogen $0.016 \%$ (Kjeldahl extraction, Jackson 1965), available phosphorus $0.042 \%$ (blue color method using ascorbic acid, Olsen et al. 1954), exchangeable potassium $0.030 \%$ (Pratt, 1965), available sulfur 0,0048\% (Turbidimetric method, Bardsley and Lancaster 1965), sand $4.66 \%$, silt $68.33 \%$ and clay $27.01 \%$, textural class- silt loam (Bouyoucos 1962), moisture content was $12.32 \%$ and field capacity was $32.3 \%$ (Gardner 1986). The concentrations of total iron (2310 $\mathrm{mg} / \mathrm{kg})$, manganese $(421 \mathrm{mg} / \mathrm{kg})$, zinc $(75 \mathrm{mg} / \mathrm{kg})$ and copper $(26 \mathrm{mg} / \mathrm{kg})$ were determined using an Atomic Absorption Spectrophotometer (AAS) (VARIAN AA240).

\section{Pot experiment}

A pot experiment (Fig. 1) was carried out in the net house of the Department of Soil, Water and Environment, University of Dhaka from $20^{\text {th }}$ August 2018 to $20^{\text {th }}$ December 2018. Eight kilograms of air dried soil were placed in $10 \mathrm{~kg}$ capacity pot providing a drainage hole at the bottom. Eight treatments with three replications were as follows: Control (- $\mathrm{Cu}$ and $\mathrm{VC}$ ), $\mathrm{VC}_{5}$ ton/ha, $\mathrm{Cu}_{0.5} \mathrm{~kg} / \mathrm{ha}, \mathrm{Cu}$ kg/ha, $\mathrm{Cu}_{1.5}$ $\mathrm{kg} / \mathrm{ha}, \mathrm{Cu}_{0.5} \mathrm{~kg} / \mathrm{ha}+\mathrm{VC}_{5}$ ton/ha, $\mathrm{Cu}_{1} \mathrm{~kg} / \mathrm{ha}+\mathrm{VC}_{5}$ ton/ha, and $\mathrm{Cu}_{1.5} \mathrm{~kg} / \mathrm{ha}+\mathrm{VC}_{5}$ ton/ha. Pots were arranged in a completely randomized design (CRD). Urea, TSP and MP fertilizers were applied in quantities of $20 \mathrm{~kg} / \mathrm{ha}, 15 \mathrm{~kg} / \mathrm{ha}$ and $30 \mathrm{~kg} / \mathrm{ha}$, respectively in each pot as basal dose. Copper was used as $\mathrm{CuSO}_{4} 5 \mathrm{H}_{2} \mathrm{O}$. Vermicompost was collected from Charfession, Bhola district. The total $\mathrm{N}, \mathrm{P}$ and $\mathrm{K}$ concentrations of vermicompost were $1.10,0.29$ and $0.82 \%$, respectively. Certified seeds of cowpea, Vigna unguiculata, were collected from "Quality Seed Company", Siddique Bazar, Dhaka. Three healthy seeds were sown to each pot and water was applied up to field capacity. One healthy seedling was kept in each pot. The pots were watered thrice a week in the morning. Plant height, the number of leaf and leaf area per plant were recorded at 60 and 120 days. Fruit number and length were measured and recorded during the harvest of cowpea at 120 days.

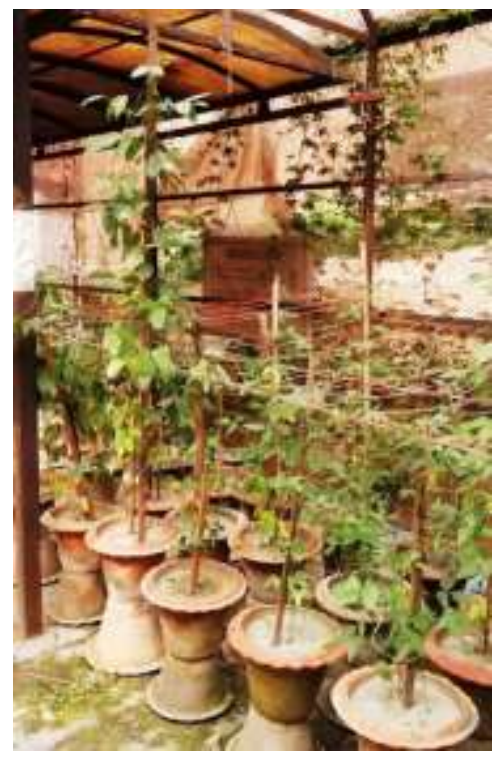

a

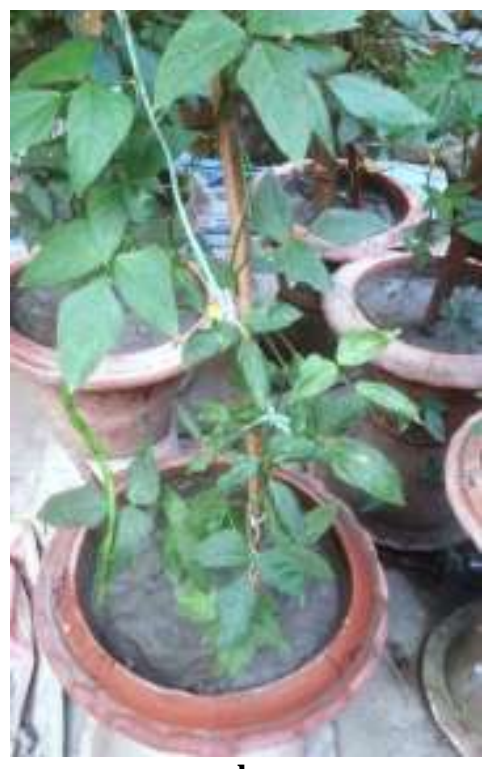

b

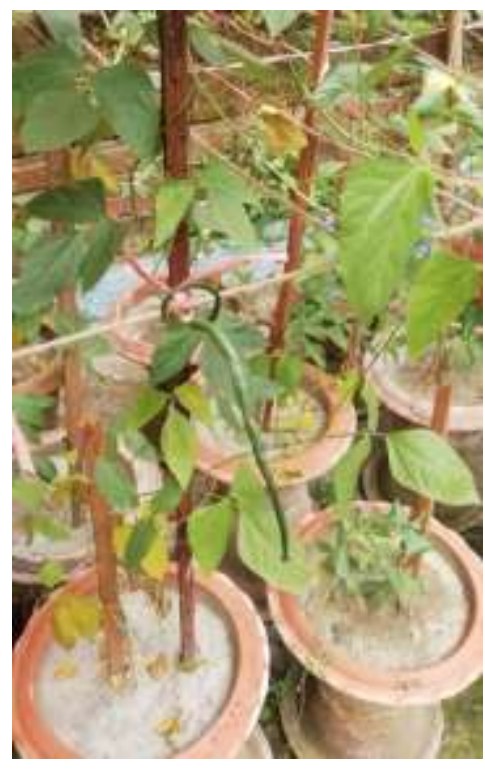

c

Fig. 1. Pictorial view of Cowpea (Vigna unguiculata L.) Walp harvesting: a. pot experiments; b. growing plant in a pot; and c. harvest in $\mathrm{Cu}_{0.5} \mathrm{~kg} / \mathrm{ha}+\mathrm{VC}_{5}$ ton/ha treatment. 


\section{Harvesting}

The plants were harvested as root, stem, leaf and fruit. The roots were washed with tap water and finally with distilled water to remove any adhering particles on the root surface. Samples were air-dried in room temperature and finally oven-dried at $65^{\circ} \mathrm{C}$ for 48 hours in the laboratory. The dry weight of the samples was recorded and the samples were ground with a mechanical grinder and stored in plastic containers for further chemical analysis. For nitrogen, $0.5 \mathrm{~g}$ of yield (fruit) sample was digested in a Kjeldahl digestion flask (Jackson 1965), for P and K $0.5 \mathrm{~g}$ yield (fruit) was digested (Jackson 1965). Phosphorus of the digest was determined by vanadomolybdophosphoric yellow color method at $430 \mathrm{~nm}$ using spectrophotometer (model DR 5000). Potassium in the digest was determined by using JENWAY flame photometer (model PFP 7). For sulfur $0.5 \mathrm{~g}$ yield (fruit) sample was digested with $\mathrm{HNO}_{3}-\mathrm{HClO}_{4}$ acid. After digestion the extract was used to determine the total sulfur content by turbidimetric method (Bardsley and Lancaster 1965). For total $\mathrm{Cu}, \mathrm{Zn}, \mathrm{Fe}$ and $\mathrm{Mn} 0.5 \mathrm{~g}$ yield (fruit) sample was digested with $\mathrm{HNO}_{3}$ and $\mathrm{HClO}_{4}$ acid and the total concentrations of $\mathrm{Cu}, \mathrm{Zn}, \mathrm{Fe}$ and $\mathrm{Mn}$ were determined by the Atomic Absorption Spectrophotometer (AAS) (VARIAN AA240). LSD test of the results was performed using IBM SPSS, version 25.

\section{RESULTS AND DISCUSSION}

Plant growth, yield and nutrient accumulation in the fruits were assessed in terms of plant height, leaf number and leaf area (Table 1), yield attribute (Table 2), and macro and micro nutrients concentration in the fruits of cowpea (Table 3). Height, leaf number and leaf area of cowpea increased with time and varied significantly $(\mathrm{p} \leq 0.05)$ (Table 1$)$. However, the highest height $(226.67 \mathrm{~cm})$ was observed in $\mathrm{Cu}_{0.5} \mathrm{~kg} / \mathrm{ha}+\mathrm{VC}_{5}$ ton/ha treatment. Chemical fertilizer offered the nutrients that were readily soluble in soil solution and thereby instantaneously available to plants. Nutrient availability from organic sources was due to microbial action and improved physical condition of soil. Results of this experiment are in agreement with Sarker et al. (2004).

Table 1. Effects of copper and vermicompost on the height $(\mathrm{cm})$, leaf number (number/plant) and leaf area $\left(\mathrm{cm}^{2} /\right.$ plant) of cowpea (Vigna unguiculata L.) Walp.

\begin{tabular}{|c|c|c|c|c|c|c|}
\hline \multirow[t]{2}{*}{ Treatments } & \multicolumn{2}{|c|}{ Plant Height } & \multicolumn{2}{|c|}{ Leaf Number } & \multicolumn{2}{|c|}{ Leaf Area } \\
\hline & 60 days & 120 days & 60 days & 120 days & 60 days & 120 days \\
\hline Control(- $\mathrm{Cu}$ and $\mathrm{VC})$ & 45.67 & 153.33 & 17.67 & 43.67 & 38.13 & 96.38 \\
\hline $\mathrm{VC}_{5}$ ton/ha & 50.00 & 167.33 & 21.67 & 67.67 & 67.42 & 125.50 \\
\hline $\mathrm{Cu}_{0.5} \mathrm{~kg} / \mathrm{ha}$ & 60.67 & 177.33 & 27.00 & 64.67 & 59.65 & 121.05 \\
\hline $\mathrm{Cu}_{1} \mathrm{~kg} / \mathrm{ha}$ & 53.33 & 160 & 20.33 & 51.33 & 55.33 & 114.05 \\
\hline $\mathrm{Cu}_{1.5} \mathrm{~kg} / \mathrm{ha}$ & 58.00 & 183.33 & 23.33 & 60.33 & 55.12 & 118.62 \\
\hline $\mathrm{Cu}_{0.5} \mathrm{~kg} / \mathrm{ha}+\mathrm{VC}_{5}$ ton $/ \mathrm{ha}$ & 80.00 & 226.67 & 28.33 & 86.33 & 79.87 & 174.12 \\
\hline $\mathrm{Cu}_{1} \mathrm{~kg} / \mathrm{ha}+\mathrm{VC}_{5}$ ton $/ \mathrm{ha}$ & 66.67 & 209.67 & 25.33 & 75.00 & 69.72 & 161.59 \\
\hline $\mathrm{Cu}_{1.5} \mathrm{~kg} / \mathrm{ha}+\mathrm{VC}_{5}$ ton $/ \mathrm{ha}$ & 60.33 & 169.67 & 20.67 & 60.67 & 55.92 & 116.01 \\
\hline LSD at $5 \%$ & 3.49 & 2.23 & 1.59 & 2.01 & 0.43 & 1.57 \\
\hline
\end{tabular}

The highest value of leaf number was 86.33 recorded in $\mathrm{Cu}_{0.5} \mathrm{~kg} / \mathrm{ha}+\mathrm{VC}_{5}$ ton/ha treatment at harvest. The number of leaf significantly increased with the combined application of organic and inorganic fertilizer. Results are in agreement with Sharma (2000), who found that the integrated application of organic and inorganic fertilizers significantly increased vegetative growth. Khadir et al. (2002) also observed that combined application of different inorganic and organic fertilizers increased both vegetative and leaf number in cabbage. Leaf area was maximum $\left(174.12 \mathrm{~cm}^{2} / \mathrm{plant}\right)$ in $\mathrm{Cu}_{0.5} \mathrm{~kg} / \mathrm{ha}$ $+\mathrm{VC}_{5}$ ton/ha treatment. The second highest value $\left(161.59 \mathrm{~cm}^{2} /\right.$ plant $)$ was obtained in $\mathrm{Cu}_{1} \mathrm{~kg} / \mathrm{ha}+\mathrm{VC}_{5}$ ton/ha treatment. The application of vermicompost in combination with chemical fertilizer resulted in 
high leaf area index. The result is in agreement with Jeyabal and Kuppuswamy (2001), who reported that with a higher leaf area index, plants become photosynthetically more active, which would contribute to the improvement in yield attributes. Vermicompost contained numerous humic acids, which enhances the number of leaf, leaf area index, plant height and increased the growth rate (Atarzadeh et al. 2013).

\section{Dry matter yield}

Dry weights of root, stem and leaf are presented in Table 2 , varied significantly $(\mathrm{p} \leq 0.05)$. The highest yields of root, stem and leaf were achieved due to the combined application of inorganic and organic fertilizer in $\mathrm{Cu}_{0.5} \mathrm{~kg} / \mathrm{ha}+\mathrm{VC}_{5}$ ton/ha treatment. The maximum dry weight was $13.98 \mathrm{~g} / \mathrm{plant}$, found in $\mathrm{Cu}_{0.5} \mathrm{~kg} / \mathrm{ha}+\mathrm{VC}_{5}$ ton/ha treatment.

Results of the fruit length and fruit number per plant of cowpea during harvest, presented in Table 2, varied significantly $(\mathrm{p} \leq 0.05)$. The maximum fruit length $(52.4 \mathrm{~cm})$ of cowpea was observed in $\mathrm{Cu}_{0.5}$ $\mathrm{kg} / \mathrm{ha}+\mathrm{VC}_{5}$ ton/ha treatment. The second highest fruit length $(36 \mathrm{~cm})$ was found in $\mathrm{Cu}_{1} \mathrm{~kg} / \mathrm{ha}+\mathrm{VC}_{5}$ ton/ha treatment. The lowest fruit length $(18 \mathrm{~cm})$ was observed in control. The maximum number of fruit per plant was six, observed in $\mathrm{Cu}_{0.5} \mathrm{~kg} / \mathrm{ha}+\mathrm{VC}_{5}$ ton/ha treatment. The second highest number of fruit per plant was five, recorded in $\mathrm{VC}_{5}$ ton/ha, $\mathrm{Cu}_{1} \mathrm{~kg} / \mathrm{ha}, \mathrm{Cu}_{1.5} \mathrm{~kg} / \mathrm{ha}$ and $\mathrm{Cu}_{1} \mathrm{~kg} / \mathrm{ha}+\mathrm{VC}_{5}$ ton/ha treatments, respectively. The minimum number of fruit per plant was two, found in control. This increase in yield attributes might be due to the high levels of organic nutrients in vermicompost that could boost up the vegetative growth of cowpea plants to accelerate the photosynthetic rate. Treatments that received vermicompost significantly increased yield compared to control. However, the maximum yield (fruit) $(5.65 \mathrm{~g} / \mathrm{plant})$ obtained in combination of copper and vermicompost in $\mathrm{Cu}_{0.5} \mathrm{~kg} / \mathrm{ha}+\mathrm{VC}_{5}$ ton/ha treatment.

Table 2. Effects of copper and vermicompost on the yield attributes and yield of cowpea (Vigna unguiculata L.) Walp.

\begin{tabular}{|c|c|c|c|c|c|c|c|}
\hline Treatments & $\begin{array}{c}\text { Dry weight } \\
\text { of root } \\
\text { (g/ plant) } \\
\end{array}$ & $\begin{array}{c}\text { Dry weight } \\
\text { of stem } \\
\text { (g/plant) } \\
\end{array}$ & $\begin{array}{c}\text { Dry weight } \\
\text { of leaf } \\
\text { (g/plant) } \\
\end{array}$ & $\begin{array}{c}\text { Total } \\
\text { (g/plant) }\end{array}$ & $\begin{array}{l}\text { Fruit } \\
\text { length } \\
(\mathrm{cm}) \\
\end{array}$ & $\begin{array}{c}\text { Fruit } \\
\text { number }\end{array}$ & $\begin{array}{c}\begin{array}{c}\text { Fruit } \\
\text { yield } \\
\text { (g/plant) }\end{array} \\
\end{array}$ \\
\hline Control(- $\mathrm{Cu}$ and $\mathrm{VC})$ & 0.86 & 3.98 & 3.78 & 8.62 & 18 & 2 & 1.96 \\
\hline $\mathrm{VC}_{5}$ ton $/ \mathrm{ha}$ & 1.80 & 6.43 & 4.04 & 12.27 & 30 & 5 & 5.25 \\
\hline $\mathrm{Cu}_{0.5} \mathrm{~kg} / \mathrm{ha}$ & 2.00 & 6.19 & 4.60 & 12.79 & 32 & 4 & 5.13 \\
\hline $\mathrm{Cu}_{1} \mathrm{~kg} / \mathrm{ha}$ & 1.60 & 5.80 & 4.69 & 12.09 & 26.3 & 5 & 4.83 \\
\hline $\mathrm{Cu}_{1.5} \mathrm{~kg} / \mathrm{ha}$ & 1.65 & 5.62 & 4.46 & 11.73 & 29.6 & 5 & 5.17 \\
\hline $\mathrm{Cu}_{0.5} \mathrm{~kg} / \mathrm{ha}+\mathrm{VC}_{5}$ ton/ha & 2.09 & 7.13 & 4.76 & 13.98 & 52.4 & 6 & 5.65 \\
\hline $\mathrm{Cu}_{1} \mathrm{~kg} / \mathrm{ha}+\mathrm{VC}_{5}$ ton/ha & 2.04 & 6.84 & 4.40 & 13.28 & 36 & 5 & 4.53 \\
\hline $\mathrm{Cu}_{1.5} \mathrm{~kg} / \mathrm{ha}+\mathrm{VC}_{5}$ ton $/ \mathrm{ha}$ & 1.88 & 4.07 & 4.33 & 10.28 & 28 & 4 & 4.48 \\
\hline LSD at $5 \%$ & 0.31 & 0.74 & 0.27 & - & 1.87 & 0.84 & 0.87 \\
\hline
\end{tabular}

Mean values of total macro and micro nutrient concentrations in the fruits of cowpea as affected by copper and vermicompost are presented in Table 3 . The results varied significantly $(\mathrm{p} \leq 0.05)$ at $5 \%$ level. The average $\mathrm{N}$ concentration in the fruits ranged from 4.29 to $2.10 \%$. The highest total $\mathrm{N}$ concentration $\left(4.29 \%\right.$ ) recorded in $\mathrm{Cu}_{1.5} \mathrm{~kg} / \mathrm{ha}+\mathrm{VC}_{5}$ ton/ha treatment. The maximum amount of total $\mathrm{P}$ $(0.79 \%)$ in the fruits was obtained in $\mathrm{Cu}_{0.5} \mathrm{~kg} / \mathrm{ha}+\mathrm{VC}_{5}$ ton/ha treatment. The second highest total $\mathrm{P}$ value $(69 \%)$ was found in $\mathrm{Cu}_{1.5} \mathrm{~kg} / \mathrm{ha}+\mathrm{VC}_{5}$ ton/ha treatment. The highest total $\mathrm{K}(4.14 \%)$ in the fruits was obtained in $\mathrm{Cu}_{0.5} \mathrm{~kg} / \mathrm{ha}+\mathrm{VC}_{5}$ ton/ha treatment. The second highest $\mathrm{K}$ concentration $(3.82 \%)$ was achieved in $\mathrm{Cu}_{1.5} \mathrm{~kg} / \mathrm{ha}+\mathrm{VC}_{5}$ ton/ha treatment. The highest total sulfur $(0.42 \%)$ in the fruits was obtained in $\mathrm{Cu}_{0.5} \mathrm{~kg} / \mathrm{ha}+\mathrm{VC}_{5}$ ton/ha treatment. The lowest total $\mathrm{N}(2.10 \%), \mathrm{P}(0.20 \%), \mathrm{K}(1.79 \%)$ and $\mathrm{S}$ $(0.06 \%)$ were observed in control. The highest total $\mathrm{Cu}(27 \mathrm{mg} / \mathrm{kg})$ in the fruits was obtained in $\mathrm{Cu}_{0.5}$ $\mathrm{kg} / \mathrm{ha}+\mathrm{VC}_{5}$ ton/ha treatment. The highest total $\mathrm{Zn}(88 \mathrm{mg} / \mathrm{kg})$ in the fruits was obtained in $\mathrm{Cu}_{1.5} \mathrm{~kg} / \mathrm{ha}+$ 
$\mathrm{VC}_{5}$ ton/ha treatment. The highest total $\mathrm{Fe}(640 \mathrm{mg} / \mathrm{kg})$ and $\mathrm{Mn}(59 \mathrm{mg} / \mathrm{kg})$ in fruits were obtained in $\mathrm{Cu}_{0.5} \mathrm{~kg} / \mathrm{ha}+\mathrm{VC}_{5}$ ton/ha treatment. The lowest total $\mathrm{Cu}(10 \mathrm{mg} / \mathrm{kg}), \mathrm{Zn}(42 \mathrm{mg} / \mathrm{kg}), \mathrm{Fe}(132 \mathrm{mg} / \mathrm{kg})$ and Mn $(21 \mathrm{mg} / \mathrm{kg})$ were recorded in control. The maximum amount of total macro and micro nutrients concentration in the fruits of cowpea was possibly due to proper balance of organic and inorganic fertilizers in $\mathrm{Cu}_{0.5} \mathrm{~kg} / \mathrm{ha}+\mathrm{VC}_{5}$ ton/ha and $\mathrm{Cu}_{1.5} \mathrm{~kg} / \mathrm{ha}+\mathrm{VC}_{5}$ ton/ha treatments.

Table 3. Effects of copper and vermicompost on macro and micro nutrients concentrations in the fruits of cowpea (Vigna unguiculata L.) Walp.

\begin{tabular}{|c|c|c|c|c|c|c|c|c|}
\hline Treatments & $\mathrm{N}(\%)$ & $\mathbf{P}(\%)$ & $\mathbf{K}(\%)$ & S (\%) & $\mathrm{Cu}$ (mg/kg) & Zn (mg/kg) & Fe (mg/kg) & Mn (mg/kg) \\
\hline Control(- $\mathrm{Cu}$ and $\mathrm{VC})$ & 2.10 & 0.20 & 1.79 & 0.06 & 10 & 42 & 132 & 21 \\
\hline $\mathrm{VC}_{5}$ ton $/ \mathrm{ha}$ & 2.53 & 0.57 & 3.46 & 0.28 & 24 & 84 & 329 & 44 \\
\hline $\mathrm{Cu}_{0.5} \mathrm{~kg} / \mathrm{ha}$ & 2.94 & 0.50 & 3.21 & 0.26 & 21 & 77 & 279 & 37 \\
\hline $\mathrm{Cu}_{1} \mathrm{~kg} / \mathrm{ha}$ & 2.53 & 0.49 & 3.29 & 0.23 & 20 & 59 & 321 & 46 \\
\hline $\mathrm{Cu}_{1.5} \mathrm{~kg} / \mathrm{ha}$ & 4.27 & 0.62 & 3.15 & 0.27 & 26 & 59 & 467 & 43 \\
\hline $\mathrm{Cu}_{0.5} \mathrm{~kg} / \mathrm{ha}+\mathrm{VC}_{5}$ ton $/ \mathrm{ha}$ & 3.24 & 0.79 & 4.14 & 0.42 & 27 & 62 & 640 & 59 \\
\hline $\mathrm{Cu}_{1} \mathrm{~kg} / \mathrm{ha}+\mathrm{VC}_{5}$ ton $/ \mathrm{ha}$ & 2.55 & 0.57 & 3.63 & 0.32 & 20 & 58 & 388 & 38 \\
\hline $\mathrm{Cu}_{1.5} \mathrm{~kg} / \mathrm{ha}+\mathrm{VC}_{5}$ ton $/ \mathrm{ha}$ & 4.29 & 0.69 & 3.82 & 0.33 & 26 & 88 & 632 & 47 \\
\hline LSD at $5 \%$ & 0.15 & 0.05 & 0.16 & 0.06 & 0.84 & 0.93 & 1.22 & 0.98 \\
\hline
\end{tabular}

The experiment revealed that copper and vermicompost shared better effects on growth and yield attribute significantly of Cowpea (Vigna unguiculata L.) Walp. Better growth and yield were achieved in $\mathrm{Cu}_{0.5} \mathrm{~kg} / \mathrm{ha}+\mathrm{VC}_{5}$ ton/ha treatment and nutrient accumulation in the fruits was found in $\mathrm{Cu}_{0.5} \mathrm{~kg} / \mathrm{ha}+$ $\mathrm{VC}_{5}$ ton/ha and $\mathrm{Cu}_{1.5} \mathrm{~kg} / \mathrm{ha}+\mathrm{VC}_{5}$ ton/ha treatments, respectively.

\section{REFERENCES}

Aira, M. and J. Dominguez. 2008. Optimizing vermicomposting of animal wastes: effects of rate of manure application on carbon loss and microbial stabilization. J. Environ. Manage. 88: 1525-1529.

Atarzadeh, S. H., M. Mojaddam and T. S. Nejad. 2013. The interactive effects humic acid application and several of nitrogen fertilizer on remobilization star wheat. Int. J. Biosci. 3(8): 116-123.

Bardsley, C. E. and J. D. Lancaster. 1965. Sulfur. In: C. A. Black (ed). Methods of Soil Analysis. Part 2. American Society of Agronomy, Inc., Madison, Wisconsin, USA., pp. 1102-1114.

Bouyoucos, G. J. 1962. Hydrometer method improved for making particle size analysis of soils. Agron. J. 54: 464-465.

Gardner, W. H. 1986. Water content. In: A. Klute (ed). Methods of Soil Analysis. Part 1. 2nd ed. American Society of Agronomy, Inc., Soil Science Society of America, Inc., Madison, Wisconsin, USA., pp. 439-541.

Jackson, M. L. 1965. Soil chemical analysis. Prentice-Hall Inc., New York, USA. 498 pp.

Jeyabal, A. and G. Kuppuswamy. 2001. Recycling of organic wastes for the production of vermicompost and its response in rice-legume cropping system and soil fertility. Eu. J. Agron. 15(13): 153-170.

Khadir, G. A., S. K. Marazat and S. A. Sadoun. 2002. Effect of different levels of urea fertilizers and plant spacing on growth and yield of cabbage. Dirasat. 16: 88-105. 
Mordtvedt, J. J., F. R. Cox, L. M. Shuman and R. M. Welch. 1991. Micronutrients in Agriculture. SSS of America, Madison, Wisconsin, USA., pp. 280-339.

Olsen, S. R., C. V. Cole, F. S. Watanabe and L. A. Dean. 1954. Estimation of available phosphorus in soils by extraction with sodium bicarbonate. U.S. Dept. Agr. Circ. 939 pp.

Pratt, P. F. 1965. Potassium. In: C. A. Black (ed). Methods of Soil Analysis. Part 2. American Society of Agronomy, Inc., Madison, Wisconsin, USA., pp. 1022-1030.

Rahman, M. M. 1989. Progress and prospect of minor pulses in Bangladesh. In: K. Jagdish (ed.). Advances in Pulse Research in Bangladesh. BARC, Bangladesh., pp. 43-50.

Rangel, A., G. B. Domont, C. Pedrosa and S. T. Ferreira. 2003. Functional properties of purified vicilins from cowpea (Vigna unguiculata) and pea (Pisum sativum) and cowpea protein isolate. J. Agric. Food Chem. 51(19): 5792-5797.

Sarker, M. A. R., M. Y. A. Pramanik, G. M. Faruk and M. Y. Ali. 2004. Effect of green manures and levels of nitrogen on some growth attributes of transplant Aman rice. Pakistan J. Biol. Sci. 7: 739742.

Sharma, K. C. 2000. Influence of integrated nutrient management on yield and economics in broccoli (Brassica oleracea L.) plant under cold temperate conditions. Vegetable Sci. 27: 62-63.

Walkley, A. and I. A. Black. 1934. An examination of the Degtjareff method for determining soil organic matter and a proposed modification of the chromic acid titration method. Soil Sci. 37: 2938.

Witthoft, C. and M. Hefni. 2016. Encyclopedia of Food and Health. Academic Press, Oxford, UK., pp. 724-730. 